\title{
KONTRIBUSI MINAT BELAJAR, LINGKUNGAN SEKOLAH DAN PROFESIONALISME GURUTERHADAP HASIL BELAJAR PAI SMP
}

\author{
Muhammad Irsan Barus \\ Dosen Pendidikan Agama Islam Universitas Medan Area \\ mirsanbarus@gmail.com
}

\begin{abstract}
The main objective of this study to reveal the contributions: (1) interest in learning for learning outcomes PAI: (2) the school environment for learning outcomes PAI: (3) the professionalism of teachers on learning outcomes PAI: (4) interest in learning, the school environment, and the professionalism of teachers together on learning outcomes PAI. This study consists of three independent variables, namely interest in learning, the school environment, and the professionalism of teachers. The dependent variable is the result of learning PAI. The study population of 170 people. The sample was selected by proportional random sampling technique as many as 135 people. Data interest in learning, the school environment, and the professionalism of teachers is obtained by distributing questionnaires to 135 students, while the data on learning outcomes obtained through the semester exam results document. Data were analyzed using multiple regression test. Research findings indicate (1) the learning interest accounted for $17.8 \%$ of the PAI learning outcomes; (2) the school environment accounted for $17.9 \%$ of the PAI learning outcomes; (3) the professionalism of teachers accounted for $19.5 \%$ of the PAI learning outcomes; (4) interest in learning, the school environment and teacher professionalism contributed significantly by $28.1 \%$ to the learning outcomes PAI and $71.9 \%$ are influenced by other factors not examined in this study.
\end{abstract}

Keywords: Interest in Learning, School Environment, Professional Teacher Learning Outcomes PAI SMP

\begin{abstract}
ABSTRAK
Tujuan utama penelitian ini untuk mengungkapkan kontribusi: (1) minat belajar terhadap hasil belajar PAI: (2) lingkungan sekolah terhadap hasil belajar PAI: (3) profesionalisme guru terhadap hasil belajar PAI: (4) minat belajar, lingkungan sekolah, dan profesionalisme guru secara bersamasama terhadap hasil belajar PAI. Penelitian ini terdiri atas tiga variabel bebas, yaitu minat belajar, lingkungan sekolah, dan profesionalisme guru. Variabel terikatnya adalah hasil belajar PAI. Populasi penelitian 170 orang. Sampel dipilih dengan teknik proportional random sampling sebanyak 135 orang. Data minat belajar, lingkungan sekolah, dan profesionalisme guru diperoleh dengan mengedarkan angket kepada 135 peserta didik, sedangkan data tentang hasil belajar diperoleh melalui dokumen hasil ujian semester. Data dianalisis menggunakan uji regresi berganda. Temuan hasil penelitian menunjukkan (1) minat belajar berkontribusi sebesar 17,8\% terhadap hasil belajar PAI; (2) lingkungan sekolah berkontribusi sebesar 17,9\% terhadap hasil belajar PAI; (3) profesionalisme guru berkontribusi sebesar 19,5\% terhadap hasil belajar PAI; (4) minat belajar, lingkungan sekolah dan profesionalisme guru berkontribusi secara signifikan sebesar $28,1 \%$ terhadap hasil belajar PAI dan $71,9 \%$ dipengaruhi oleh faktor lain yang tidak diteliti dalam penelitian ini.
\end{abstract}

Kata Kunci: Minat Belajar, Lingkungan Sekolah, Profesionalisme Guru Hasil Belajar PAI SMP

\section{PENDAHULUAN}

Hasil belajar erat kaitannya dengan ketercapaian salah satu tujuan pendidikan (Daradjat, 2009). Hasil belajar merupakan tolak ukur yang utama untuk mengetahui keberhasilan belajar seseorang dalam mengikuti sebuah jenjang pendidikan. Hasil belajar yang memuaskan menunjukkan tingkat penguasaan peserta didik terhadap materi yang disampaikan oleh guru sudah 
maksimal. Seluruh dimensi yang berkaitan dengan proses pembelajaran bermuara pada hasil yang dicapai peserta didik. (Slameto, 2013).

Menurut Gagne hasil belajar adalah kepemilikan kapabilitas berupa keterampilan, sikap, dan nilai (Dimyati \& Mudjiono, 2006) Artinya, belajar membawa suatu perubahan pada individu yang belajar. Perubahan itu tidak hanya mengenai jumlah pengetahuan yang diperoleh, melainkan juga dalam bentuk kecakapan, kebiasaan, sikap, pengertian, penghargaan, minat, dan penyesuaian diri (Nasution, 1995).

Gagne berpendapat ada beberapa faktor internal dan eksternal yang mempengaruhi hasil belajar. Faktor eksternal meliputi guru, perangkat kurikulum, sarana dan prasarana, dana, manajemen serta masukan dari masyarakat. Sedangkan faktor internal meliputi motivasi belajar, kecerdasan intelegensi peserta didik, minat, perhatian, sikap, kebiasaan belajar, ketekunan, sosial ekonomi, serta faktor fisik dan psikis (Gagne dan Brigg, 1988)

Sedangkan menurut Dunkin dan Biddle faktor yang mempengaruhi hasil belajar dikelompokkan kepada beberapa bagian, yaitu presage varibles, context variables, process varibles dan product variables. Interaksi pendidikan disebut process variables yang dipengaruhi oleh: (1) presage variables (variabel latar belakang) yang merupakan kemampuan-kemampuan yang dimiliki oleh guru yaitu meliputi pendidikan, keterampilan dan pengalaman belajar, motivasi guru dan sebagainya, (2) variables context (variabel konteks) yang berkaitan dengan berbagai kondisi, baik kondisi peserta didik, sekolah, ruangan kelas yang setiap hari dihadapi guru dalam proses pembelajaran. Sedangkan product variables (variabel hasil belajar) merupakan perubahan tingkah laku yang terjadi pada diri peserta didik sebagai akibat dari interaksi pendidikan yang berlangsung antara guru dan peserta didik di bawah pengaruh presage dan context variables (Nurdin, 1994)

Muhibbin Syah membedakan faktorfaktor yang mempengaruhi hasil belajar menjadi tiga, yakni: (1) internal (dari dalam peserta didik), yakni kondisi jasmani dan rohani; meliputi fisiologis dan psikologis (inteligensi, sikap, bakat, minat, motivasi); (2) eksternal (dari luar peserta didik), lingkungan; meliputi lingkungan sosial (sekolah, masyarakat dan tetangga serta teman-teman sepermainan di sekitar tempat tinggal) dan lingkungan non-sosial (gedung sekolah dan letaknya, rumah tempat tinggal dan letaknya, alat-alat belajar, keadaan cuaca dan waktu belajar); dan (3) pendekatan (aproach to learning), yakni jenis upaya belajar yang meliputi strategi dan metode yang digunakan untuk melakukan kegiatan pembelajaran (Muhibbin Syah, 2012).

Salah satu faktor internal yang memberikan kontribusi terhadap hasil belajar adalah minat belajar. Minat adalah kecendrungan dan kegairahan yang tinggi atau keinginan yang besar terhadap sesuatu. (Muhibbin Syah, 2012)

Selain itu, faktor yang memberikan kontribusi terhadap hasil belajar adalah lingkungan sekolah. Menurut Blocher bahwa lingkungan sekolah adalah suatu konteks fisik, sosial, dan psikologis yang dalam konteks tersebut anak belajar dan memperoleh perilaku baru (Mariyana, 2010). Lingkungan sekolah adalah tempat anak bereksplorasi, bereksperimen dan mengekspresikan diri untuk mendapat konsep dan informasi baru sebagai wujud dari hasil belajar.

Selain dua faktor di atas, faktor lain yang menentukan hasil belajar adalah profesionalisme guru. Guru merupakan ujung tombak implementasi kurikulum. Semua potensi peserta didik tidak akan berkembang secara optimal tanpa bantuan guru. Berdasarkan kajian Pullias dan Young (1998), 
Manan (1990), serta Yelon and Weinstein (1997), bahwa sedikitnya ada 19 peran guru. Sebagai pendidik, pengajar, pembimbing, pelatih, penasehat, pembaharu (inovator), model dan teladan, pribadi, peneliti, pendorong kreativitas, pembangkit pandangan, pekerja rutin, pemindah kemah, pembawa cerita, aktor, emansipator, evaluator, pengawet dan kulminator (Mulyasa, 2007)

Berdasarkan hasil observasi dan pengamatan penulis, ternyata hasil belajar PAI masih rendah. Hasil belajar rendah tersebut bisa dilihat pada tabel di bawah ini: (Program SPPS versi 16.00)

Tabel 1.

\section{Deskripsi Frekuensi Hasil Belajar}

\begin{tabular}{|c|c|c|c|c|}
\hline \multirow{2}{*}{$\mathrm{N} 0}$. & \multirow{2}{*}{ Kelas Interval } & \multicolumn{2}{|c|}{ Frekuensi } & \multirow{2}{*}{ Keterangal } \\
\hline & & Fi & $\%$ & \\
\hline 1 & $94-100$ & 22 & $12,94 \%$ & \multirow{3}{*}{ Tuntas } \\
\hline 2 & $87-93$ & 19 & $11,17 \%$ & \\
\hline 3 & $80-86$ & 29 & $17,05 \%$ & \\
\hline 4 & $73-79$ & 23 & $13,52 \%$ & \\
\hline 5 & $66-72$ & 22 & $12,94 \%$ & \multirow{4}{*}{ Tidak Tuntas } \\
\hline 6 & $59-65$ & 31 & $18,23 \%$ & \\
\hline 7 & $52-58$ & 21 & $12,35 \%$ & \\
\hline 8 & $45-51$ & 3 & $1,76 \%$ & \\
\hline \multicolumn{2}{|r|}{ Jumlah } & 170 & $100 \%$ & \\
\hline \multicolumn{2}{|c|}{ Mean } & \multicolumn{3}{|c|}{74.9118} \\
\hline \multicolumn{2}{|c|}{ Median } & \multicolumn{3}{|c|}{75.0000} \\
\hline \multicolumn{2}{|c|}{ Modus } & \multicolumn{3}{|c|}{75.00} \\
\hline & tandar deviasi & \multicolumn{3}{|c|}{1.3761661} \\
\hline & Koefisien variasi $(\%)$ & \multicolumn{3}{|c|}{189.383} \\
\hline & Vilai maksimum & \multicolumn{3}{|c|}{100} \\
\hline & Vilai minimum & \multicolumn{3}{|c|}{50} \\
\hline
\end{tabular}

Berdasarkan Tabel 1 di atas diperoleh gambaran rata-rata nilai hasil belajar peserta didik adalah 74.9118. Artinya, rata-rata nilai peserta didik masih berada di bawah KKM 75. Selain itu, jumlah peserta didik yang tuntas atau nilainya berada di atas KKM 75 yaitu 73 orang $(42,94 \%)$ dan peserta didik yang tidak tuntas atau nilainya berada di bawah KKM 75 yakni 97 orang (57,044\%). Hal ini menunjukkan tingkat penguasaan peserta didik terhadap mata pelajaran PAI belum memenuhi kriteria kelulusan minimal yang telah ditetapkan.

Adapun Identifikasi masalah yang ditemukan disajikan dalam bentuk skema hubungan berikut:

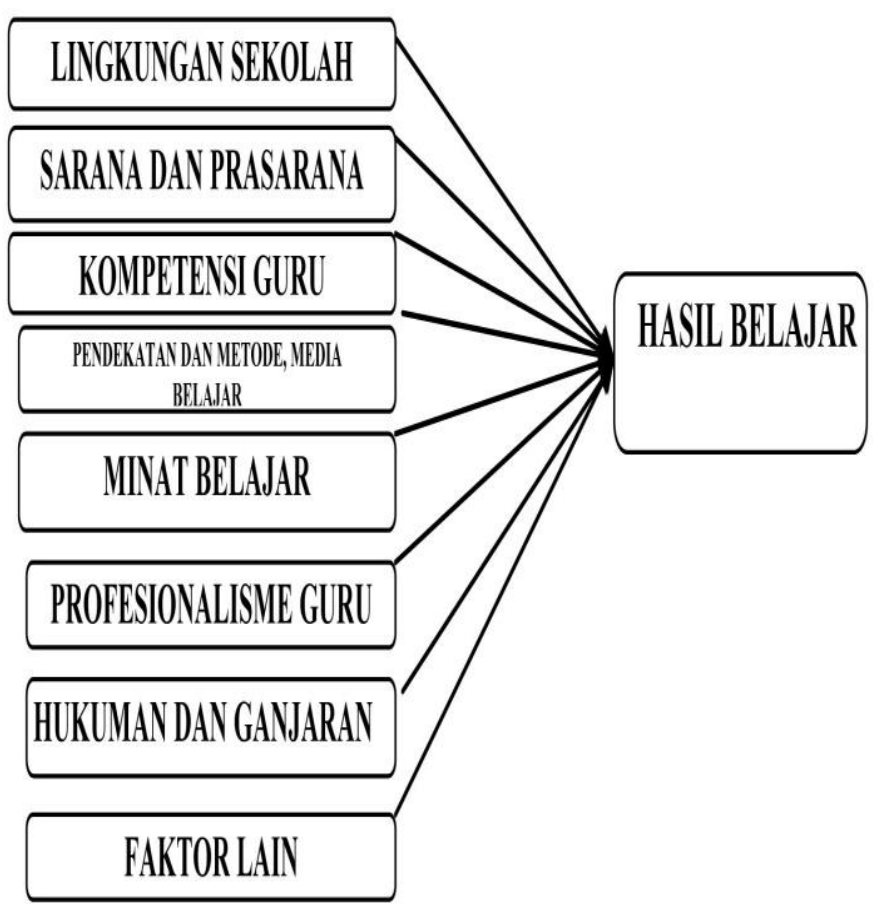

Gambar 1.

\section{Hubungan Antar Variabel Yang} Mempengaruhi Hasil Belajar

Banyak faktor yang berkontribusi terhadap hasil belajar. Faktor- faktor yang akan dimasukkan dalam penelitian ini hanya tiga, yaitu minat belajar, lingkungan sekolah dan profesionalisme guru sebagai variabel bebas dan hasil belajar sebagai variabel terikat.

Berdasarkan penjelasan tersebut, hubungan variabel yang akan dibahas dalam penelitian ini hanya dibatasi pada: 1) kontribusi minat belajar terhadap hasil belajar 
PAI SMP Padang, 2) kontribusi lingkungan sekolah terhadap hasil belajar PAI SMP Padang, 3) kontribusi profesionalisme guru terhadap hasil belajar PAI 2 Padang, dan 4) kontribusi minat belajar, lingkungan sekolah dan profesionalisme guru secara bersamasama terhadap hasil belajar PAI SMP Padang. Batasan masalah digambarkan pada skema berikut:

\section{Gambar 2.}

Skema Batasan Masalah

Pada Variabel Penelitian

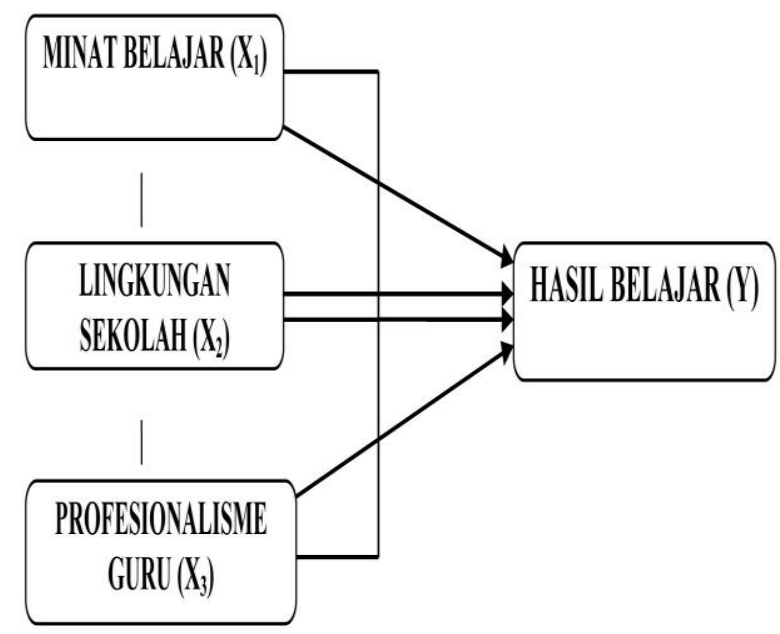

Hipotesis yang diajukan dalam penelitian ini dapat dilihat pada tabel di bawah ini.

\section{Tabel 2. Hipotesis Penelitian}

\begin{tabular}{|l|l|l|}
\hline \multirow{2}{*}{1} & $\mathrm{H}_{\mathrm{a}}$ & Minat belajar berkontribusi terhadap hasil belajar \\
\cline { 2 - 4 } & $\mathrm{H}_{0}$ & $\begin{array}{l}\text { Minat belajar tidak berkontribusi terhadap hasil } \\
\text { belajar }\end{array}$ \\
\hline 2 & $\mathrm{H}_{\mathrm{a}}$ & $\begin{array}{l}\text { Lingkungan sekolah berkontribusi terhadap hasil } \\
\text { belajar }\end{array}$ \\
\cline { 2 - 4 } & $\mathrm{H}_{0}$ & $\begin{array}{l}\text { Lingkungan sekolah tidak berkontribusi terhadap } \\
\text { hasil belajar }\end{array}$ \\
\hline \multirow{2}{*}{3} & $\mathrm{H}_{\mathrm{a}}$ & $\begin{array}{l}\text { Profesionalisme guru berkontribusi terhadap } \\
\text { hasil belajar }\end{array}$ \\
\cline { 2 - 3 } & $\mathrm{H}_{0}$ & $\begin{array}{l}\text { Profesionalisme tidak guru berkontribusi } \\
\text { terhadap hasil belajar }\end{array}$ \\
\hline & $\mathrm{H}_{\mathrm{a}}$ & $\begin{array}{l}\text { Minat belajar, lingkungan belajar dan } \\
\text { profesionalisme guru secara bersama- sama } \\
\text { berkontribusi terhadap hasil belajar }\end{array}$ \\
\cline { 2 - 3 } & $\mathrm{H}_{0}$ & $\begin{array}{l}\text { Minat belajar, lingkungan belajar dan } \\
\text { profesionalisme guru secara bersama-sama tidak } \\
\text { berkontribusi terhadap hasil belajar }\end{array}$ \\
\hline
\end{tabular}

\section{METODE PENELITIAN}

Penelitian ini menggunakan metode deskriptif yaitu pencarian fakta dengan interpretasi yang tepat. (Nazir, 2003). Sampel penelitian sebanyak 135 orang sesuai dengan tabel penentuan jumlah sampel menurut Isacc dan Michael. (Isaac \& Michael, 1981). Adapun penyusunan angket yang digunakan dalam penelitian ini merujuk pada skala Likert. (Fraenkel, 1993)

Analisis data bertujuan untuk mengetahui kontribusi minat belajar $\left(\mathrm{X}_{1}\right)$, lingkungan sekolah $\left(\mathrm{X}_{2}\right)$, dan profesionalisme guru $\left(\mathrm{X}_{3}\right)$ terhadap hasil belajar $(\mathrm{Y})$. Adapun teknik analisis yang dipakai adalah:

\section{a. Uji F}

Digunakan untuk mengetahui apakah variabel bebas secara bersama-sama berkontribusi secara signifikan terhadap variabel terikat. Rumusnya:

$$
F_{\text {hitung }}=\frac{R^{2} / k}{\left(1-R^{2}\right)(n-k-1)}
$$

Keterangan :

$$
\begin{array}{ll}
\mathrm{R}^{2} & \begin{array}{l}
\text { : Koefisien determinasi } \\
\text { berganda }
\end{array} \\
\mathrm{k} & : \text { Banyaknya variabel bebas } \\
\mathrm{n} & : \text { Besarnya sampel } \\
\mathrm{F}_{\text {hitung }} & : \text { Nilai F yang di hitung }
\end{array}
$$

Kriteria pengujian:

- Apabila $F_{\text {hitung }}>F_{\text {tabel }}$, maka $\mathrm{H}_{0}$ ditolak dan $\mathrm{H}_{\mathrm{a}}$ diterima. Artinya, terdapat kontribusi variabel bebas secara bersamasama terhadap variabel terikat.

- Apabila $F_{\text {hitung }}<F_{\text {tabel }}$, maka $\mathrm{H}_{0}$ diterima dan $\mathrm{H}_{\mathrm{a}}$ ditolak. Artinya, tidak terdapat kontribusi variabel bebas secara bersamasama terhadap variabel terikat.

Dengan tingkat kepercayaan $(\alpha)$ untuk pengujian ini adalah $95 \%$ atau $\alpha=0,05$. 


\section{b. Uji Koefisien Determinasi ( $\mathbf{R}^{\mathbf{2}}$ )}

Untuk mengetahui kontribusi dari variabel independen terhadap variabel dependen dapat dilihat dari adjusted $R$ square nya. Koefisien ini dapat digunakan untuk menganalisis apakah variabel yang diduga / diramal (Y) dipengaruhi oleh variabel (X). Rumusnya:

$$
R^{2}=\frac{E S S}{T S S}
$$

$$
R^{2} \text { adjusted }=1-\left(1-R^{2}\right) \frac{n-1}{(n-k)}
$$

\section{c. Uji t}

Uji t bertujuan untuk melihat kontribusi dari masing-masing variabel yaitu kontribusi variabel penyebab terhadap variabel akibat. Rumusnya:

$$
t_{k}=\frac{b_{k}}{S_{b k}}
$$

Keterangan:

$\mathrm{b}_{\mathrm{k}}=$ Koefisien regresi ke $\mathrm{k}$

$\mathrm{S}_{\mathrm{bk}}=$ Simpangan baku koefisien $\mathrm{b}$ yang ke k

Kriteria pengujian hipotesis :

- Jika $\mathrm{t}_{\text {hitung }} \geq \mathrm{t}_{\text {tabel }}$ maka $\mathrm{H}_{0}$ ditolak dan $\mathrm{H}_{\mathrm{a}}$ diterima, berarti terdapat kontribusi yang signifikan antara variabel bebas terhadap variabel terikat

- Jika $\mathrm{t}_{\text {hitung }} \leq \mathrm{t}$ tabel maka $\mathrm{H}_{0}$ diterima dan $\mathrm{H}_{\mathrm{a}}$ ditolak, berarti tidak terdapat kontribusi yang signifikan antara variabel bebas terhadap variabel terikat.

\section{HASIL PENELITIAN}

\section{a. Kontribusi Minat Belajar Terhadap Hasil Belajar}

Hipotesis pertama penelitian ini adalah terdapat kontribusi minat belajar (X1) terhadap hasil belajar (Y). Hasil perhitungan regresi sederhana dengan program SPSS 16.00 .
Didapatkan nilai $\mathrm{R}_{\text {tabel }}$ sebesar 0,429 menunjukkan koefisien korelasi antara minat belajar terhadap hasil belajar dengan nilai $R_{\text {kuadrat }}$ atau $R_{\text {square }}$ adalah 0,184. Namun analisis dalam regresi multiple nilai $R_{\text {kuadrat }}$ yang disesuaikan (adjusted $R_{\text {square }}$ ) pada tabel adalah sebesar 0,178. Pada tabel di atas Adjusted $R_{\text {Square }}$ sebesar 0,178 . Untuk mencari determinan korelasi maka 0,178 x 100 menjadi $17,8 \%$. Hal ini menunjukkan bahwa kontribusi minat belajar $\left(\mathrm{X}_{1}\right)$ terhadap hasil belajar (Y) sebesar $17,8 \%$.

Selanjutnya hasil analisis ANOVA diperoleh nilai $f_{\text {hitung }}$ yaitu 29.952 dengan tingkat signifikan 0,000 . Probabilitas 0,000 jauh < dari taraf signifikan 0,05. Hal ini menunjukkan bahwa model regresi bisa dipakai untuk memprediksi hasil belajar. Oleh karena itu, dapat dikatakan terdapat hubungan minat belajar terhadap hasil belajar.

Didapatkan juga koefisien konstanta adalah sebesar 11.965 dan koefisien regresi sebesar 0, 429 diperoleh gambaran persamaan regresi sebagai berikut: $\mathrm{Y}=\mathrm{a}+\mathrm{bX} 1$ atau $11.965+0,429$ X1. Kriteria uji koefisien regresi dari variabel minat belajar $\left(X_{1}\right)$ terhadap hasil belajar (Y) sebagai berikut:

Ha : Minat belajar $\left(\mathrm{X}_{1}\right)$ berhubungan secara signifikan terhadap hasil belajar (Y)

Ho : Minat belajar $\left(\mathrm{X}_{1}\right)$ tidak berhubungan terhadap hasil belajar (Y).

Dari hasil analisis Regresi Sederhana Variabel $\left(X_{1}\right)$ dengan Variabel $(Y)$ dapat dilihat nilai $t_{\text {hitung }}$ untuk variabel minat belajar $\left(\mathrm{X}_{1}\right)$ adalah $\mathrm{t}_{\text {hitung }} 5.473>\mathrm{t}_{\text {tabel }} 1.65639$ dengan nilai (Sig $0.000<0,05$ ), maka $\mathrm{H}_{\mathrm{a}}$ diterima. Dengan demikian dapat disimpulkan minat belajar mempunyai kontribusi yang signifikan terhadap hasil belajar PAI SMP Padang. 


\section{b. Kontribusi Lingkungan Sekolah Terhadap Hasil Belajar}

Hipotesis kedua penelitian ini adalah terdapat hubungan lingkungan sekolah $\left(\mathrm{X}_{2}\right)$ terhadap hasil belajar (Y). Hasil perhitungan korelasi/hubungan dan regresi sederhana dengan program SPSS 16.00.

Dari hasil analisis didapatkan nilai $\mathrm{R}_{\text {tabel }}$ sebesar 0,431 yang menunjukkan koefisien korelasi antara minat belajar terhadap hasil belajar, sedangkan nilai $\mathrm{R}_{\text {kuadrat }}$ atau $\mathbf{R}_{\text {square }}$ adalah 0,185 . Namun analisis dalam regresi multiple nilai $R_{\text {kuadrat }}$ yang disesuaikan (adjusted $R_{\text {square }}$ ) pada tabel adalah sebesar 0,179. Pada tabel di atas Adjusted $R_{\text {Square }}$ adalah sebesar 0,179 , untuk mencari determinan korelasi maka 0,179 x 100 menjadi $17,9 \%$. Hal ini menunjukkan bahwa kontribusi lingkungan sekolah $\left(\mathrm{X}_{2}\right)$ terhadap hasil belajar (Y) sebesar 17,9\%.

\section{Selanjutnya analisis ANOVA} diperoleh nilai $f_{\text {hitung }}$ yaitu 30.289 dengan tingkat signifikan 0,000 . probabilitas 0,000 jauh < dari taraf signifikan 0,05. Hal ini menunjukkan bahwa model regresi bisa dipakai untuk memprediksi hasil belajar. Oleh karena itu, dapat dikatakan terdapat hubungan lingkungan sekolah terhadap hasil belajar.

Selanjutnya analisis koefisien konstanta adalah sebesar 12.281 dan koefisien regresi sebesar $0, .431$ diperoleh gambaran persamaan regresi sebagai berikut: $\mathrm{Y}=\mathrm{a}+$ $\mathrm{bX}_{1}$ atau $12.281+0, .431 \mathrm{X}_{1}$. Kriteria uji koefisien regresi dari variabel lingkungan sekolah $\left(\mathrm{X}_{2}\right)$ terhadap hasil belajar (Y) sebagai berikut:

$\mathrm{Ha}$ : Lingkungan sekolah $\left(\mathrm{X}_{2}\right)$ berhubungan secara signifikan terhadap hasil belajar (Y)

Ho : Lingkungan sekolah $\left(\mathrm{X}_{2}\right)$ tidak berhubungan terhadap hasil belajar (Y).

Dari hasil analisis pada Regresi Sederhana Variabel $\left(\mathrm{X}_{2}\right)$ dengan Variabel $(Y)$ dapat dilihat nilai $t_{\text {hitung }}$ untuk variabel lingkungan sekolah $\left(\mathrm{X}_{2}\right)$ adalah $\mathrm{t}_{\text {hitung }} 5.504>$ $t_{\text {tabel }} 1.65639$ dengan nilai (Sig $0.000<0,05$ ), maka $\mathrm{H}_{\mathrm{a}}$ diterima. Dengan demikian dapat disimpulkan bahwa lingkungan sekolah mempunyai kontribusi yang signifikan terhadap hasil belajar PAI SMP Padang.

\section{c. Kontribusi Profesionalisme Guru Terhadap Hasil Belajar}

Hipotesis ketiga penelitian ini adalah terdapat hubungan profesionalisme guru $\left(\mathrm{X}_{3}\right)$ terhadap hasil belajar (Y). Hasil perhitungan korelasi/hubungan dan regresi sederhana dengan program SPSS 16.00:

Dari hasil analisis nilai $\mathrm{R}_{\text {tabel }}$ sebesar 0 , 201 yang menunjukkan koefisien korelasi antara profesionalisme guru terhadap hasil belajar peserta didik, sedangkan nilai $\mathrm{R}_{\text {kuadrat }}$ atau $\mathbf{R}_{\text {square }}$ adalah 0,195 . Analisis dalam regresi multiple nilai $R_{\text {kuadrat }}$ yang disesuaikan adalah (Adjusted $R_{\text {Square }}$ ) karena hanya menguji satu variabel independen terhadap variabel devenden. Pada tabel di atas $R_{\text {square }}$ adalah sebesar 0.195, untuk mencari determinan korelasi maka 0, 195 x 100 menjadi $19,5 \%$. Hal ini menunjukkan bahwa kontribusi profesionalisme guru $\left(\mathrm{X}_{3}\right)$ terhadap hasil belajar (Y) sebesar 19,5\%.

Selanjutnya dari hasil analisis ANOVA diperoleh nilai $f_{\text {hitung }}$ yaitu 33.508 dengan tingkat signifikan 0,000 . probabilitas 0,000 jauh < dari taraf signifikan 0,05. Hal ini menunjukkan bahwa model regresi bisa dipakai untuk memprediksi hasil belajar. Oleh karena itu, dapat dikatakan terdapat hubungan profesionalisme guru terhadap hasil belajar.

Selanjutnya analisis koefisien konstanta adalah sebesar 7.164 dan koefisien regresi sebesar 0, 449 diperoleh gambaran persamaan regresi sebagai berikut: $\mathrm{Y}=\mathrm{a}+\mathrm{bX}_{1}$ atau $7.164+0,449 X_{1}$. Kriteria uji koefisien regresi dari variabel profesionalisme guru $\left(\mathrm{X}_{1}\right)$ terhadap hasil belajar (Y) sebagai berikut: 
Ha : Profesionalisme guru $\left(\mathrm{X}_{3}\right)$ berhubungan secara signifikan terhadap hasil belajar (Y)

Ho : Profesionalisme guru $\left(\mathrm{X}_{3}\right)$ tidak berhubungan terhadap hasil belajar (Y).

Dari hasil analisis Regresi Sederhana Variabel $\left(X_{3}\right)$ dengan Variabel $(Y)$ dapat dilihat nilai $t_{\text {hitung untuk variabel }}$ profesionalisme guru $\left(\mathrm{X}_{3}\right)$ adalah $\mathrm{t}_{\text {hitung }} 5.789$ $>t_{\text {tabel }} 1.65639$ dengan nilai (Sig $0.000<$ 0,05), maka $\mathrm{H}_{\mathrm{a}}$ diterima. Dengan demikian dapat disimpulkan bahwa profesionalisme guru mempunyai kontribusi yang signifikan terhadap hasil belajar PAI SMP Padang.

\section{d. Kontribusi Minat Belajar, Lingkungan Sekolah dan Profesionalisme Guru Secara Bersama-Sama Terhadap Hasil Belajar}

Hipotesis keempat penelitian ini adalah terdapat hubungan minat belajar $\left(\mathrm{X}_{1}\right)$, lingkungan sekolah $\left(\mathrm{X}_{2}\right)$ dan profesionalisme guru $\left(\mathrm{X}_{3}\right)$ terhadap hasil belajar $(\mathrm{Y})$. Hasil perhitungan korelasi/hubungan dan regresi berganda dengan program SPSS 16.00.

Dari hasil analisis regresi berganda sebagai berikut:

$\mathrm{Y}=\mathrm{a}+\mathrm{b}_{1} \mathrm{X}_{1}+\mathrm{b}_{2} \mathrm{X}_{2}+\mathrm{b}_{3} \mathrm{X}_{3}$

$\mathbf{Y}=-24,275+\mathbf{0}, 469 \mathbf{X}_{1}+\mathbf{0}, 475 \mathbf{X}_{\mathbf{2}}+\mathbf{0}, 216$

$\mathbf{X}_{3}$

Persamaan regresi tersebut diketahui nilai konstanta sebesar $-24,275$ artinya tanpa adanya variabel minat belajar $\left(\mathrm{X}_{1}\right)$, lingkungan sekolah $\left(\mathrm{X}_{2}\right)$, dan profesionalisme guru $\left(\mathrm{X}_{3}\right)$, maka hasil belajar adalah -24,275. Kontribusi masing-masing variabel bebas (minat belajar, lingkungan sekolah dan profesionalisme guru) yang mempengaruhi variable terikat (hasil belajar) adalah:

(1) Bentuk hubungan minat belajar $\left(X_{1}\right)$ terhadap hasil belajar adalah positif sebesar 0,469. Koefisien regresi bernilai positif artinya terjadi hubungan positif antara minat belajar terhadap hasil belajar dengan nilai $t_{\text {hitung }} 2,575>\mathrm{t}_{\text {tabel }} 1.97824$ dengan nilai (Sig 0,011<0,05). Hal ini menunjukkan bahwa minat belajar berhubungan signifikan terhadap hasil belajar. Setiap peningkatan minat belajar sebesar 1 satuan akan meningkatkan hasil belajar sebesar 0,469.

(2) Bentuk hubungan lingkungan sekolah $\left(\mathrm{X}_{2}\right)$ terhadap hasil belajar adalah positif sebesar 0, 475. Koefisien regresi bernilai positif artinya terjadi hubungan positif antara lingkungan sekolah terhadap hasil belajar. Dengan nilai $\mathrm{t}_{\text {hitung }} 2,613>\mathrm{t}_{\text {tabel }}$ 1.97824 dengan nilai (Sig $0,010<0,05$ ). Hal ini menunjukkan bahwa lingkungan sekolah berhubungan signifikan terhadap hasil belajar. Setiap peningkatan lingkungan sekolah sebesar 1 satuan akan meningkatkan hasil belajar sebesar 0, 475 .

(3) Bentuk hubungan profesionalisme guru $\left(\mathrm{X}_{3}\right)$ terhadap hasil belajar adalah positif sebesar 0,216. Koefisien regresi bernilai positif artinya terjadi hubungan positif antara profesionalisme guru terhadap hasil belajar. Dengan nilai $t_{\text {hitung }} 2,640>t_{\text {tabel }}$ 1.97824 dengan nilai (Sig 0,009 $<0,05$ ). Hal ini menunjukkan bahwa profesionalisme guru berhubungan signifikan terhadap hasil belajar. Setiap peningkatan profesionalisme guru sebesar 1 satuan akan meningkatkan hasil belajar sebesar 0, 216.

Jadi, berdasarkan hasil analisis regresi berganda diperoleh nilai konstanta negatif sebesar -24,275 dan (sig 0,064<0,05), yang berarti bahwa minat belajar, lingkungan sekolah dan profesionalisme guru berhubungan positif dan signifikan terhadap hasil belajar. Dimana semakin tinggi minat belajar, lingkungan sekolah dan profesionalisme guru maka hasil belajar akan semakin tinggi. 


\section{a) Uji F}

Uji F dilakukan adalah untuk mengetahui apakah semua variabel bebas, yaitu minat belajar, lingkungan sekolah dan profesionalisme guru secara bersama-sama memiliki kontribusi yang signifikan terhadap variabel terikat hasil belajar.

Dari hasil pengolahan data nilai signifikansi hipotesis secara simultan adalah sebesar 0,000. Hal ini menunjukkan bahwa nilai signifikansi lebih $<0,05$, maka berarti hipotesis diterima $\left(\mathrm{H}_{\mathrm{a}}\right.$ diterima). Dari hasil pengolahan data juga dapat dilihat hasil dari $F_{\text {hitung }}$ sebesar $18,478>$ dari $F_{\text {tabel }}$ sebesar 2,67. Artinya $\mathrm{H}_{0}$ ditolak dan $\mathrm{H}_{\mathrm{a}}$ diterima atau dengan kata lain minat belajar, lingkungan sekolah dan profesionalisme guru berkontribusi terhadap hasil belajar SMP Padang.

\section{b) Koefisien Determinasi $\left(\mathbf{R}^{\mathbf{2}}\right)$}

Koefesien determinasi $R^{2}$ pada intinya mengukur seberapa jauh kemampuan model dalam menerangkan variasi variabel dependen. Adjusted $R^{2} \quad$ berarti $R^{2}$ sudah disesuaikan dengan derajat bebas dari masingmasing kuadrat yang tercakup di dalam perhitungan adjusted $R^{2}$.

Dari hasil analisis didadatkan nilai Adjusted $\mathrm{R}_{\text {Square }}$ sebesar 0,281. Hal ini mengindikasikan bahwa keterlibatan minat belajar, lingkungan sekolah dan profesionalisme guru terhadap hasil belajar sebesar $28,1 \%$, sedangkan sisanya sebesar $71,9 \%$ dipengaruhi oleh faktor lain yang tidak diteliti dalam penelitian ini.

\section{c) Uji t}

Uji t digunakan untuk mengetahui tingkat signifikansi variabel bebas (minat belajar, lingkungan sekolah dan profesionalisme guru) terhadap variabel terikat (hasil belajar). Acuan yang digunakan adalah jika $t_{\text {hitung }} \geq t_{\text {tabel }}$ atau nilai Sig. $\leq 0,05$ maka $\mathrm{H}_{\mathrm{a}}$ diterima. Akan tetapi, jika $\mathrm{t}_{\text {hitung }}<$ $t_{\text {tabel }}$ atau nilai Sig. $\geq 0,05$ maka $\mathrm{H}_{\mathrm{a}}$ ditolak dan $\mathrm{H}_{0}$ diterima.

\section{SIMPULAN}

Hasil analisis dapat digambarkan kesimpulan untuk pengujian hipotesis penilaian sebagai berikut.

(1) Hipotesis 1

Hipotesis pertama diuji dalam penelitian ini adalah untuk mengetahui signifikansi kontribusi minat belajar $\left(\mathrm{X}_{1}\right)$ terhadap hasil belajar (Y). Dari hasil analisis pada Tabel Analisis Regresi Linear Berganda dapat dilihat nilai $t_{\text {hitung }}$ untuk variabel minat belajar $\left(\mathrm{X}_{1}\right)$ adalah $\mathrm{t}_{\text {hitung }} 2,575>\mathrm{t}_{\text {tabel }} 1.97824$ dengan nilai (Sig 0,011<0,05), maka $\mathrm{H}_{\mathrm{a}}$ diterima. Dengan demikian dapat disimpulkan bahwa minat belajar mempunyai kontribusi yang signifikan terhadap hasil belajar SMP Padang.

(2) Hipotesis 2

Hipotesis kedua diuji dalam penelitian ini adalah untuk mengetahui signifikansi kontribusi lingkungan sekolah $\left(\mathrm{X}_{2}\right)$ terhadap hasil belajar (Y). Dari hasil analisis pada Tabel Analisis Regresi Linear Berganda dapat dilihat nilai $t_{\text {hitung }}$ untuk variabel lingkungan sekolah $\left(\mathrm{X}_{2}\right)$ adalah nilai $\mathrm{t}_{\text {hitung }} 2,613>\mathrm{t}_{\text {tabel }}$ 1.97824 dengan nilai (Sig 0,010<0,05), maka $\mathrm{H}_{\mathrm{a}}$ diterima. Dengan demikian dapat disimpulkan bahwa lingkungan sekolah mempunyai kontribusi yang signifikan terhadap hasil belajar SMP Padang.

(3) Hipotesis 3

Hipotesis ketiga diuji dalam penelitian ini adalah untuk mengetahui signifikansi kontribusi profesionalisme guru $\left(\mathrm{X}_{3}\right)$ terhadap hasil belajar (Y). Dari hasil analisis pada Tabel Analisis Regresi Linear Berganda dapat dilihat nilai $t_{\text {hitung }}$ untuk variabel profesionalisme guru $\left(\mathrm{X}_{3}\right)$ adalah nilai $\mathrm{t}_{\text {hitung }}$ 2,640 $>\mathrm{t}_{\text {tabel }} 1.97824$ dengan nilai (Sig 0,009 $<0,05)$, maka $\mathrm{H}_{\mathrm{a}}$ diterima. Dengan demikian dapat disimpulkan bahwa profesionalisme 
guru mempunyai kontribusi yang signifikan terhadap hasil belajar SMP Padang.

\section{DAFTAR PUSTAKA}

Ainley, M., Hillman, K., \& Hidi, S. (2002). Gender and interest processes in response to literary texts: situational and individual interest. Learning and Instruction, 12, 411-428.

Aksan, N., \& Kisac, B. (2009). A descriptive study: Reading comprehension and cognitive awareness skills. Procedia Social and Behavioral Sciences, 1, 834-837.

Alexander, P. A., \& Wade, S. E. (2000). Contexts that promote interest, selfdetermination, and learning: lasting impressions and lingering questions. Computers in Human Behavior, 16, 349-358.

Cox, K. E., \& Guthrie, J. T. (2001). Motivational and Cognitive Contributions to Students' Amount of Reading. Contemporary Educational Psychology, 26, 116-131.

Deci, E. L., Koestner, R., \& Ryan, R. M. (2001). Extrinsic rewards and intrinsic motivation in education: Revisited once again. Review of Educational Research, 7(1), 1-27.

Durik, A. M., Vida, M., \& Eccles, J. S. (2006). Task values and ability beliefs as predictors of high school literacy choices: A developmental analysis Journal of Educational Psychology, 98(2), 392-393.

Edmunds, K. M., \& Bauserman, K. L. (2006). What Teachers Can Learn About Reading Motivation Through Conversations With Children. The Reading Teacher, 59(5), 414-424.

Guthrie, J. T., Hoa, A. L. W., Wigfield, A., Tonks, S. M., Humenick, N. M., \& Littles, E. (2007). Reading motivation and reading comprehension growth in the later elementary years. Contemporary Educational Psychology, 32, 282-313.

Guthrie, J. T., Hoa, L. W., Wigfield, A., Tonks, S. M., \& Perencevich, K. C. (2006). From spark to fire: Can situational reading interest lead to long-term reading motivation? Literacy Research and Instruction, 45(2), 91-117.

Guthrie, J. T., Wigfield, A., Humenick, N. M., Perencevich, K. C., Taboada, A., \& Barbosa, P. (2006). Influences of Stimulating Tasks on Reading Motivation and Comprehension. The Journal of Educational Research, 99, 232-245.

Guthrie, J. T., Wigfield, A., \& VonSecker, C. (2000). Effects of integrated instruction on motivation and strategy use in reading Journal of Educational Psychology, 92(2), 331-341.

Hidi, S. (2006). Interest: A unique motivational variable. Educational Research Review, 1, 69-82.

Hidi, S., \& Renninger, K. A. (2006). The four-phase model of interest development. Educational Psychologist, 41, 111-127.

Krapp, A. (2002). Structural and dynamic aspects of interest development: theoretical considerations from an ontogenetic perspective. Learning and Instruction, 12, 383-409.

Krapp, A. (2005). Basic needs and the development of interest and intrinsic motivational orientations. Learning and Instruction, 15, 381-395.

Manguel, A. (1997). A History of Reading; The New York Time Book Review

Marinak, B. A., \& Gambrell, L. B. (2008). Intrinsic Motivation and Rewards: What Sustains Young Children's Engagement with Text? Literacy Research and Instruction, 47, 9-26. 
Marinak, B. A., \& Gambrell, L. B. (2010). Reading Motivation: Exploring the Elementary Gender Gap. Literacy Research and Instruction, 49(2), 129141.

McWhaw, K., \& Abrami, P. C. (2001). Student Goal Orientation and Interest: Effects on Students' Use of SelfPecjak, S., \& Peklaj, C. (2006). Dimensions of reading motivation and reading achievement in 3rd and 7th grade students. Studia Psychologica, 48(1), 11-30.

Pintrich, P. R., \& Schunk, D. H. (1996). Motivation in Education; Theory, Research, and Applications. . Engglewood Cliffs: Preatice-Hall.

Renninger, K. A., Ewen, L., \& Lasher, A. K. (2002). Individual interest as context in expository text and mathematical word problems. Learning and Instruction, 12, 467-491.

Schiefele, U., \& Krapp, A. (1996). Topic interest and free recall of expository text. learning and Individual Diflerences, 8(2), 141-160.

Strommen, L. T., \& Mates, B. F. (2004). Learning to love reading: Interviews with older children and teens. Journal of Adolescent \& Adult Literacy, 48, 188-200.

Tin, T. B. (2006). Investigating the nature of 'interest' reported by a group of postgraduate students in an MA in
Regulated Learning Strategies. Contemporary Educational Psychology, 26, 311-329.

Merisuo-Storm, T. (2006). Girls and Boys Like to Read and Write Different Texts. Scandinavian Journal of Educational Research, 50(2), 111125.

English language teacher education programme. System 34, 34, 222-238.

Valleley, R. J., \& Shriver, M. D. (2003). An examination of the effects of repeated readings with secondary students. Journal of Behavioral Education, 12, 55-76.

Wang, J. H. Y., \& Guthrie, J. T. (2004). Modeling the effects of intrinsic motivation, extrinsic motivation, amount of reading, and past reading achievement on text comprehension between U.S. and Chinese students. Reading Research Quarterly, 39, 162186.

Watkins, M. W., \& Coffey, D. Y. (2004). Reading Motivation: Multidimensional and Indeterminate. Journal of Educational Psychology, 91(1), 110-118.

Wigfield, A., Guthrie, J. T., Tonks, S., \& Perencevich, K. C. (2004). Children's motivation for reading: domain specificity and instructional influences. Journal of Educational Research, 97, 299-309., 97, 299-309. 